\title{
Wayne Palmer
}

Indonesia's Overseas Labour Migration Programme, 1969-2010. Leiden: Brill, xiv + 202 pp. ISBN 9789004325449, price: USD 90.00 (hardback).

Globalization and the intensification of the migration process have for some time generated questions among scholars regarding state sovereignty, territoriality, and power. In dealing with the question of whether states are losing control in an era of globalization, the contradictions and dilemmas related to state power and territoriality have become a major area of debate (Sassen 1996). Others have linked the question of 'legality' and 'illegality' as constituting various ambiguities and indeterminacies (De Genova 2002: 424). Wayne Palmer's book provides a significant contribution to this discussion as it examines the tensions and contradictions within and between state institutions in dealing with overseas migration of Indonesian workers. Utilizing the conceptual notion of 'discretion', Palmer shows how the law is interpreted and applied through personalized regimes made by Indonesian executive agencies and individuals in dealing with prospective migrants. The legitimacy of these acts of discretion is often obtained through the utilization of context-based dynamics or different interpretations of the law by state institutions. These dynamics are structurally situated within the competing interests between the different Indonesian state institutions, particularly that of the Ministry of Manpower and the BNP2TKI (The National Board for the Placement and Protection of Indonesian Overseas Workers).

In order to provide the reader with an understanding of these dynamics underlying the migration industry, we are first given an overview of the historical trajectory of migration policies throughout the years, from the New Order until the present period. Seen as an alternative source of foreign exchange and revenues, in addition to the opportunity to strengthen individual selfenrichment of the official bureaucrats, the creation of channels to send migrants abroad was manifested in the establishment of formal and informal bodies to regulate the migration process. Not only are there tensions between state institutions, but also between central and provincial units when the decentralization process was at its height. And these different bodies had their own collaborations with private intermediaries to channel migrants abroad. In addition to this, there were also the disparate geographical and institutional locations of the different offices which reinforced miscommunication and competing interests between the departments. These competing roles could also be seen after the Nunukan case, where 400,000 people were deported from Malaysia, and 70 people died. Attempts to campaign for legal reform and imple-

(C) RATNA SAPTARI, 2018 | DOI:10.1163/22134379-17402016 
ment stronger governance of the recruitment and sending procedures after this tragic incident failed because of the different interests involved (Ford 2006).

This contestation at the center, where different views persist regarding the scope of authority of each state institution and also their relationships with the private recruitment companies, is then made more complicated as one follows the dynamics in the different localities. Here we can observe how the provincial Manpower Office and the local units of BNP2TKI compete for power and money in Jakarta, Tanjung Pinang, Medan, Semarang, Nunukan and Surabaya. For instance, both Tanjung Pinang and Medan are important embarkation points for those who go to West Malaysia but each port shows different dynamics in the administrative procedures or the channels possible as local officials allow the bending of regulations as part of their acts of 'discretion'. Complications also occur as different documents are required to allow migrants to travel. For instance in Semarang, the Manpower Office issued (tax) exemption letters to migrants instead of ID cards whereas the BNP2TKI still issued ID cards and in fact the regional head of police in Semarang was requested to crack down on migrant workers without this card.

The 'culture' of introducing aspal (asli tapi palsu which means 'real but fake') documents which are obtained outside the official procedures (but often through official state agents) has also become a common feature of the migration industry (Ford and Lyons 2011: 108)

The boundaries of legality are made even more complicated as migrants cross different state borders involving different laws and patterns of discretion of actors and institutions in the receiving countries, whether these are the Indonesian labor attachés, the employers, or the local police. In Hong Kong, Indonesian migrants who are able to travel only by obtaining loans from the recruiting agencies have to hand over their passports to the recruiting company as security. In Kuala Lumpur and Singapore, the employers are the ones who retain migrants' passports. These incidents have become standard practice, especially since in some cases this is legally allowed with the introduction of an MoU between the Indonesian and Malaysian governments to prevent workers from 'running away' and choosing other employers (Killias 2010: 906). In Kuala Lumpur a zero-tolerance policy has been introduced to deal with exploitative and illegal migration, where the applicant and employer have to sign a standard employment contract provided by the embassy before migrants can collect their new passports. These policies on the one hand allow the Manpower Office to control the recruitment and employment process. but on the other hand, with the discretionary practices and individualization of the handling of administrative issues, the placement and employment process becomes 
seriously complicated, opening the way for corruption and the creation of 'illegal' migrants.

This book provides a highly valuable insight into the workings of the structures of power at the state level but also at the different points of departure or transit and in the receiving areas. We come to understand individual discretionary decisions at these different points, which provide us with an awareness of the multiple scales one has to examine for a comprehensive understanding. And although we do not see much of the resourcefulness and strategies of migrant workers in dealing with institutional obstructions, this study helps to sharpen our analysis of the migration industry. It also encourages us to reflect on the strategic alliances that need to be formed in the campaign to protect migrant workers.

\section{Ratna Saptari}

Leiden University

rsaptari@fsw.leidenuniv.nl

\section{References}

De Genova, Nicholas P. (2002). 'Migrant "Illegality" and Deportability in Everyday Life', Annual Review of Anthropology Vol. 31: 419-447.

Ford, Michele. (2006). 'After Nunukan: The Regulation of Indonesian Migration to Malaysia', in: Amarjit Kaur and Ian Metcalfe (eds), Mobility, Labour Migration and Border Controls in Asia, pp. 23-51. Basingstoke: Palgrave Macmillan.

Ford, Michele and Lenore Lyons. (2011). 'Travelling the Aspal Route; Grey Labour Migration Through an Indonesian Border Town', in: Edward Aspinall and Gerry van Klinken (eds), The State and Illegality in Indonesia, pp. 107-122. Leiden: KIT LV Press. Killias, Olivia. (2010). " "Illegal” Migration as Resistance: Legality, Morality and Coercion in Indonesian Domestic Worker Migration to Malaysia', Asian Journal of Social Science Vol. 38: 897-914.

Sassen, Saskia. (1996). Losing Control? Sovereignty in an Age of Globalization. New York: Columbia University Press. 